DOI: https://doi.org/10.31933/dijms.v2i3 Received: 3 October 2020 Revised: 6 November 2020 Publish: 25 January 2021

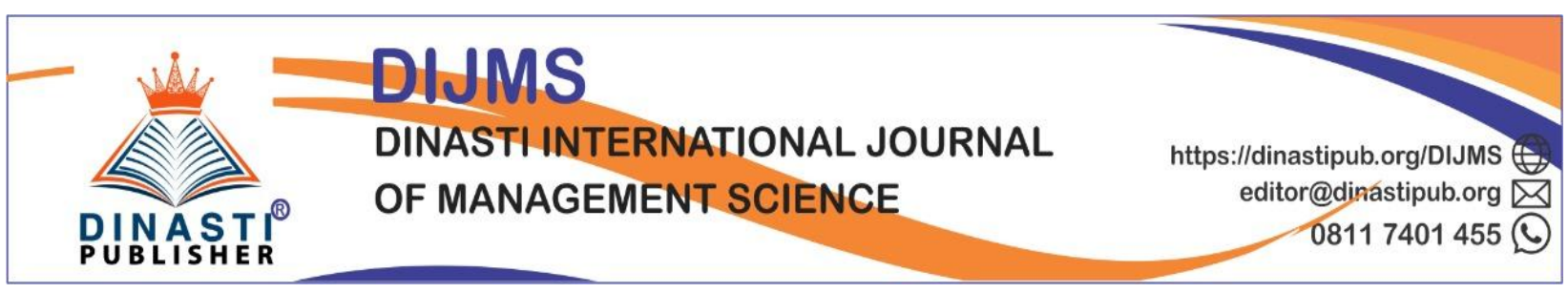

\title{
CONFLICT MODEL ON WORK MOTIVATION
}

\author{
Granit Agustina ${ }^{1}$, Feby Febrian ${ }^{2}$ \\ ${ }^{1)}$ Fakultas Ekonomi \& Bisnis Universitas Winaya Mukti, granit82.ga@gmail.com \\ ${ }^{2)}$ Fakultas Ekonomi \& Bisnis Universitas Winaya Mukti
}

Corresponding Author: First Author

Abstract: Each agency must be able to manage employees by applying appropriate conflict models according to organizational needs that can increase a person's work motivation for a job. This study aims to determine whether the functional and functional effects on employee work motivation. This research is a descriptive and verification research using path analysis, where the population of respondents is all employees of the tourism and culture office of West Java province as many as 200 people with a sample of 67 respondents using SPSS 24 software. From the results of the respondents' responses that have been distributed So simultaneously the test results show that the conflict model affects work motivation with a functional effect of 0.493 and a significant effect on dysfunctional 0.198 and simultaneously the effect of the two variables on work motivation is 0.295 . From the research results partially know that functional is more dominant in influencing work motivation than dysfunctional in the conflict model.

Keywords: conflict, functional, dysfunctional and work motivation.

\section{INTRODUCTION}

Conflicts that exist in an organization, both in government and private, generally have a good category as long as the employees or employees who work in the environment where they work can maintain harmony in their work. The number or volume of work that exceeds the capacity, the ability to master technology is still low in completing a job, the existence of differences of opinion, being slow and inaccurate in completing work can cause conflicts in work performance and organizational productivity so that it has an impact on someone's motivation to work. A large number of activities in a department are passed on to other departments, there is a difference in goals, perceptions and agreement with the suggestions of others who do not want to compromise and prefer to win alone so they are reluctant to admit that someone made a mistake will not guarantee a sense of harmony with each other in a job. The specialties that I have in work compared to others in the scope of work are wider than others and my work pace is faster than others and often repeats work so that at the final stage of the process the conflict occurs will show the results of the reactions between the parties that interacting, namely producing the 
consequences of adverse conflicts such as communication and cooperation in an organization. that is hampered and obstructed so that production and distribution activities are disrupted, giving rise to mutual suspicion, misunderstanding, and intrigue, causing each person or individual in conflict to feel anxiety, frustration, apathy and stress, if prolonged stress will make people who are in conflict withdraw from interactions and leave work and no longer have motivation to work. However, it is beneficial, especially good skills in conflict management, can make the organization more dynamic and have valuable experience, every organ of the organization, especially leaders, can be careful in making decisions, produce creative, critical, and innovative personalities, and foster tolerance.

Conflict is an effort to increase a person's motivation in work performance and organizational productivity. With regard to motivation and hygiene factors, many studies have found that motivation leads to a positive attitude, because people are willing to do things that give them what they want, which is the ultimate goal of human existence (Herzberg et al., 1959). A teacher's work motivation can be determined by job descriptions, internal functions and factors, such as individual attitudes and values. Teachers who are highly motivated should ideally work with a positive association. If teachers have a good attitude towards work, they will teach effectively and their stress will also be reduced. As for external factors, salaries, practice standards and bureaucratic organization are very important. Motivation usually increases with salary levels, so salary is an important motivator, but also depends on the teacher's performance evaluation. In addition, bureaucratic organizations can have different individual policies. Teacher work motivation can also depend on how the organizational bureaucracy motivates or suppresses them. Motivation is a series of human causes to have very strong reasons for doing what is his goal. Motivation is like a potential energy that provides direction for what activities you want to do. The occurrence of motivation is also due to various factors such as interest, need, value, attitude, aspiration, and incentive (Gage \& Berliner, 1984) while work motivation (Robbins, 2001) is an interaction between individuals and individuals, including physiological, security, social, appreciation, self-actualization.

\section{LITERATURE REVIEW}

According to Roy, A.L. and Perrin, C. (2018), Workplace conflict refers to "the process by which one party views its interests as being negatively opposed or influenced by the other" (Wall and Callister, 1995, p. 517). The non-profit sector is a relevant place for conflict studies because there are some who speak frankly, especially in the decision-making phase (Schwenk, 1990), managers and directors in non-governmental organizations (NGOs) tend to be more permissive suggesting more dominant behavior from employees when reacting to superiors (de Reuver, 2006). ; Saundry, Jones and Wibberley, 2015), and employees show high loyalty because they manage conflict in the nonprofit sector Research on the evolution of conflict is focused on analyzing interpersonal conflict at various stages (Coleman and Kugler, 2014; Ng et al., 2007). Mayer (2000, pp. 164-176) introduced a conflict sequential reframing method to track the dynamics of readjusting participants, according to evolution. I conflict and hit a dead end. Ombudsmen and managers should thus propose adaptation by means of communication and conflict managed together with conflict change (Mayer, 1974; Mayer, 1995). Interpersonal.

Conflicts within the organization are related to the organization of work or with tasks that have a negative and costly impact, such as absence, exacerbating workplace engagement (De Dreu and Weingart, 2003). An organization can then create management conflicts. In an 
interpersonal approach to conflict, dispute resolution mechanisms first identify conflictual and psychological sources, on a case-by-case basis, before attempting dispute resolution procedures (Young, 1982; Arnold and O'Connor, 1999). Researchers have proposed the application of a conflict management system (Ury et al., 1988; Lipsky et al., 2003; Le Flanchec and Rojot, 2009). The influence of culture on interdepartmental conflict is based on two types of conflict identified in functional and dysfunctional literature. Functional conflicts can be viewed as disagreements between organizational actors that can be resolved and ultimately have a positive effect on organizational processes, decision making and tenure. Dysfunctional conflict has the opposite effect, disagreements cannot be resolved and organizational processes are hampered, if not stopped altogether (cf. Menon et al., 1996). This study focuses on dysfunctional conflicts that occur between departments. Lait and Wallace (2002) study conflict in bureaucratic organizations; they found formalization and procedural rigorous conflict in business-as-usual situations. In situations requiring coordinated and innovative solutions, the rigidity of a bureaucratic culture becomes a barrier to implementation. This resulted in conflict between those trying to implement a solution and those who felt it was in their best interest to be served by maintaining the status quo. Koza and Dant (2007) studied conflict in two types of bureaucratic culture; and based on belief, that bureaucratic control structures tend to have an impact on several aspects of the organization including increased conflict, unfair conflict resolution, limited communication, and information distortion. Considering a bureaucratic culture in a marketoriented context, which requires information sharing and responsiveness to market events, one would expect both to have a higher degree of conflict and a lower market orientation.

According to Rex E. McClure, (2010) in Chuang et al. (2004) offer a conflict model based on the homogeneity of the values of members in an organization. They argue that organizations whose members have multiple interpretations are more likely to conflict with organizational values than organizations with homogeneous interpretations of surplus value. This is suggested as the salient dichotomy in this study: conflict is more likely to develop in innovative organizations than other types. It is a characteristic of innovative organizations, namely individual achievement and entrepreneurial drive, suggesting diversity values and personal goals of creating and fostering a conflict environment. Supporting this assumption, Goncalo and Staw (2006) found that organizational culture emphasizes individual achievement and creative innovation is more likely to experience destructive conflict and opportunism. Based on this study, innovative organizations are expected to have a higher incidence of conflict relative to bureaucracy and organizational ethnicity. Brotheridge and Lee (2006) examined conflict in family and organizational contexts. They found that dysfunctional conflicts were less likely to develop and were more likely to be resolved in family-like settings, including both business and family organizations. They further describe an organization such as a family as one where members have emotional bonds, share resources, and work together to improve the overall well-being of the system. They assert that the organization is like a family rooted in beliefs and an open social climate, a picture very similar to that of an organizational clan. Koza and Dant's (2007) description of trust-based organizations suggests lower levels of conflict, more equitable resolution of conflicts, greater concern for others, and increased information sharing. Extrapolating these results from kinship and belief-based to clan organizations, one would expect lower levels of conflict and higher levels of market orientation in clan organizations. Robbins in Tika (2006) defines "conflict as a process that starts when one party feels that there is another party influencing negatively, that is what the first party always pays attention to". Forms of conflict in terms of its influence on the company (Sanjaya, 2010: 30) Functional conflict, 
dysfunctional conflict, and conflict and company performance. Jackson and Shuler in Rulestari and Eryanto (2013: 21), argue that conflict has a negative impact on employee behavior, such as the emergence of work tensions, increased work turnover, decreased job satisfaction, decreased organizational commitment and decreased overall performance. Work conflicts usually arise in organizations as a result of communication problems, personal relationships and organizational structures. Work conflicts are all kinds of interactions in the form of conflicts or antagonisms between two or more parties or more that occur in the work environment (Gibson, 2006 in Ruliana, 2017). According to Patricia Dhiana Paramita (02019) Work conflict is a conflict that occurs between what a person expects of himself, other people, the organization and the reality of what he expects (Robbins, 2006 in Ruliana, 2017), Conflict in organizations has a positive impact as well as negative for the organization. Positively, the existence of conflict can improve work rhythm, make work finish quickly and increase employee discipline. Meanwhile, negatively, conflict in the organization can cause job stress, decrease job satisfaction, decrease organizational commitment and increase the intensity of leaving (intention to quit) (Rice, 2013).

Winardi argues that the basic components of motivation consist of needs, desires (expectations), behavior and goals (Winardi, 2012: 25). Furthermore, Winardi stated that there are various reasons why humans work. If we accept the view that people work for rewards, then these benefits can be broken down into two types: Extrinsic rewards such as wages / salaries, promotions, and praise. Intrinsic rewards are for example a feeling of accomplishment in performing a particular task that is very interesting and challenging. Based on some of the opinions above, motivation is always a concern because it is closely related to the work success of a person or organization in achieving its goals. Motivation is defined as behavior aimed at the target. This relates to the level of effort made by a person in pursuing his goals. Motivation is an impulse that arises in a person consciously to carry out an action with a specific purpose. The impulse can arise by itself internally or through external stimuli. Internal encouragement involves individual factors, such as personality, attitudes and perceptions of roles, while external encouragement involves organizational factors, such as work situations, participation, work discipline (supervision), and promotions. Work motivation is very important for the achievement of personal and organizational goals (Zareen et al., 2015). Previous research has shown that work

motivation is highly dependent on the extent to which employees interact, perceive and interpret transformational leader behavior (Morkevi ciūte_et al., 2019). On the other hand, the theory questions the assumption that transformational managers are the primary actors shaping motivation and conversely suggests that motivational attention may be rooted in a very personal aspect (Paustian-Underdahl et al., 2014). Some researchers underestimate the importance of examining the influence of gender on work motivation (Gunkel et al., 2007; Patton and Creed, 2001). From this point of view, the elaboration of an individual approach for each employee (irrespective of gender issues) should be a major pledge of success in evaluating the relationship between perceptions. Transformational leadership and work motivation scientific research (Arnania-Kepuladze, 2010; Leithwood and Jantzi, 1997; Morkevi ciūte and _ Endriulaitiene, 2017 _) suggest that a key aspect underlying determining the relationship between transformational leadership and work motivation is gender-related perceptions and employee preferences. . Previous studies have shown that women see managers' concerns for working conditions and employees as more important and valuable in the organizational domain than men (Hughes, 2006; Paustian-Underdahl et al., 2014). Thus, it is likely that the intrinsic motivation of female employees can increase with the increased ability of managers to maintain an 
organizational atmosphere charged with care and concern. Regarding other types of motivation, it is important to note that female employees may try to avoid performance-related success (Arnania-Kepuladze, 2010). Therefore, managers being concerned about performance can hardly generate an internal desire to work in this particular sample of employees. With management that is highly performance-oriented, only women's extrinsic motivation can be increased (ArnaniaKepuladze, 2010; Meece et al., 2006). Transformational leaders are notorious for displaying both of these behaviors. Therefore, from our point of view, different dimensions of transformational leadership can produce different motivational outcomes among female employees. Therefore, transformational leadership must be examined with regard to aspects of supportive, demanding and other behavioral aspects of this leadership style considering them separately in the context of women's motivation.

Hasibuan, (2011: 92) explains that Motivation questions how to encourage subordinates' work passion, so that they are willing to work hard by giving all their abilities and skills to realize company goals. According to Hasibuan (2011: 150) there are two types of motivation, namely positive and negative motivation. According to Ankli, R.E. and Palliam, R. (2012) The assumptions underlying motivation include: people who have the capacity to take responsibility, action, natural aspirations to learn and understand things, and the desire to do good at work and play. As an empirical-based theory of human motivation, self-determination addresses some of the basic problems associated with cognitive, affective and psycho-motor development. Selfperception, one's psychological and emotional needs, life goals and aspirations, individual dynamism, culture and the impact of the social environment are the main problems that determine a person's ability to self-actualize which is his focus, because motivation assumes different dimensions, motivation needs to be considered related issues. with autonomous motivation, controlled motivation, and motivation as a predictor of performance. With regard to motivation and hygiene factors, many studies have found that motivation leads to a positive attitude, because people are willing to do things that give them what they want, which is the ultimate goal of human existence (Herzberg et al., 1959). A teacher's work motivation can be determined by job descriptions, internal functions and factors, such as individual attitudes and values. Teachers who are highly motivated should ideally work with a positive association. If teachers have a good attitude towards work, they will teach effectively and their stress will also be reduced. As for external factors, salaries, practice standards and bureaucratic organization are very important. Motivation usually increases with salary levels, so salary is an important motivator, but also depends on the teacher's performance evaluation. In addition, bureaucratic organizations can have different individuals Policy. Teacher work motivation can also depend on how the organizational bureaucracy motivates or suppresses them. Motivation is a series of human causes to have very strong reasons for doing what is his goal. Motivation is like a potential energy that provides direction for what activities you want to do. The occurrence of motivation is also due to various factors such as interest, need, value, attitude, aspiration, and incentive (Gage \& Berliner, 1984) while work motivation (Robbins, 2001) is an interaction between individuals and individuals, including physiological, security, social, appreciation, selfactualization. 


\section{Conceptual Framework}

After conducting a literature study, I then formulated a framework to describe the relationship between functional and dysfunctional to work motivation.

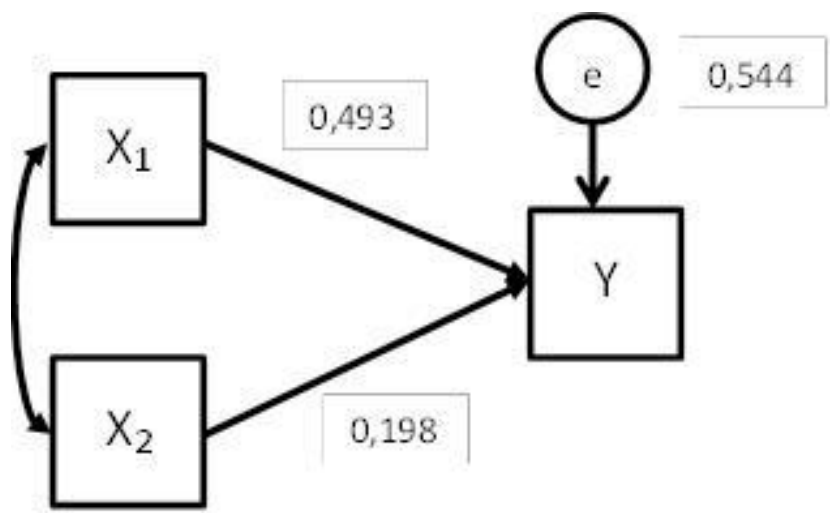

Figure 1. Conceptual Frame Work.

\section{Hypothesis}

Based on the hypothesis the conceptual model of this study is as follows:

H1: functional significant effect on work motivation

$\mathrm{H} 2$ : dysfunctional have a significant effect on work motivation

$\mathrm{H} 3$ : functional and dysfunctional have a significant effect on work motivation

\section{RESEARCH METHODS}

The research was conducted at the West Java Province Tourism and Culture Office, which is located at Jalan Laks LLRE Martadinata St No.209, Cihapit, Bandung Wetan, Bandung City, West Java 40114 through descriptive and explanatory survey methods, namely descriptive and verification. To test the effect of conflict on work motivation on employees of the West Java Province Tourism and Culture Office, primary data and secondary data are needed through interviews, questionnaires, observations and literature studies (Library Research). The population in this study were 200 employees. The minimum sample calculation for disproportionate random sampling shows that the minimum sample size needed is 67 people. The statistical test to be used in this research is path analysis, which is to test the relationship between the conflict model research variables and work motivation at the Department of Tourism and Culture of West Java Province.

\section{ANALYSIS AND DESIGN}

The validity test results of the conflict model variables and work motivation are above 0.3, which means that the value of $r$ count $>r$ table, then the variable is valid. Meanwhile, all variables are declared reliable where the overall test results are still above 0.6.

Table 1.Results of Analysis of the Validity of Item Variable X1 (Functional)

\begin{tabular}{|c|c|c|c|}
\hline 1 & 2 & 3 & 4 \\
\hline 0,71 & 0.59 & 0.63 & 0.72 \\
\hline Valid & Valid & Valid & Valid \\
\hline
\end{tabular}


Table 2. Results of Analysis of the Validity of Item Variable X2 (Dysfunctional)

\begin{tabular}{|c|c|c|c|}
\hline 1 & 2 & 3 & 4 \\
\hline 0,66 & 0.48 & 0.54 & 0.69 \\
\hline Valid & Valid & Valid & Valid \\
\hline
\end{tabular}

While the results of the comprehensive validity test for the Motivation (Y) variable can be seen in the table below:

Table 3.Results of Analysis of the Validity of Item Variable Y (Motivation)

\begin{tabular}{|l|l|l|l|l|l|l|l|l|l|}
\hline 1 & 2 & 3 & 4 & 5 & 6 & 7 & 8 & 9 & 10 \\
\hline 0,71 & 0.72 & 0.71 & 0.72 & 0.70 & 0.62 & 0.72 & 0.72 & 0.49 & 0.70 \\
\hline Valid & Valid & Valid & Valid & Valid & Valid & Valid & Valid & Valid & Valid \\
\hline
\end{tabular}

Table 4. Reliability Test Results for Variable Instruments $X_{1}, X_{2}$, and $Y$

\begin{tabular}{|c|c|c|c|} 
Variabel & $\mathrm{X}_{1}$ & $\mathrm{X}_{2}$ & $\mathrm{Y}$ \\
\hline Reliabilitas & 0.809 & 0.710 & 0.801 \\
\hline
\end{tabular}

Table 5. Correlation Matrix Between Independent Variables

\begin{tabular}{|l|l|l|l|}
\hline Variabel & $\mathrm{X} 1$ & $\mathrm{X} 2$ & $\mathrm{Y}$ \\
\hline $\mathrm{X} 1$ & 1 & 0,348 & 0,649 \\
\hline $\mathrm{X}_{2}$ & 0.348 & 1 & \\
\hline $\mathrm{Y}$ & 0.649 & & 1 \\
\hline
\end{tabular}

Table 6 is an indicator of conflict-fungcional-positive

\begin{tabular}{|c|c|c|c|}
\hline No & Statement & Score & Evidence \\
\hline 1 & Creative & 275 & Good \\
\hline 2 & Critical & 179 & Good enough \\
\hline 3 & Innovative & 185 & Good enough \\
\hline 4 & Tolerance & 278 & Good \\
\hline
\end{tabular}

Table 7 is an indicator of conflict-disfungcional-negative

\begin{tabular}{|c|c|c|c|}
\hline No & Statement & Score & Evidence \\
\hline 1 & Anxiety & 270 & Agree \\
\hline 2 & Frustration & 176 & Hesitant \\
\hline 3 & Apathy & 130 & Disagree \\
\hline 4 & Stress & 274 & Agree \\
\hline
\end{tabular}


Table 8 is an indicator of Motivation

\begin{tabular}{|l|l|l|l|}
\hline No & Statement & Score & Evidence \\
\hline 1 & Meeting needs & 275 & Agree \\
\hline 2 & Policy on providing salaries, wages and holiday allowances & 278 & Agree \\
\hline 3 & Protection at work & 276 & Agree \\
\hline 4 & Insurance coverage & 278 & Agree \\
\hline 5 & Work environment situation & 225 & Doubt \\
\hline 6 & Relationships with coworkers & 229 & Agree \\
\hline 7 & Giving awards for work performance & 277 & Agree \\
\hline 8 & Recognition of work performance & 276 & Agree \\
\hline 9 & Chance to improve & 169 & Disagree \\
\hline 10 & Chance to get training & 225 & Doubt \\
\hline
\end{tabular}

Table 9. SPSS - Coeffisein Coefficients $^{\mathrm{a}}$

\begin{tabular}{|c|c|c|c|c|c|c|}
\hline \multirow{2}{*}{\multicolumn{2}{|c|}{ Model }} & \multicolumn{2}{|c|}{ Unstandardized Coefficients } & \multicolumn{2}{|c|}{$\begin{array}{c}\text { Standa } \\
\text { rdized } \\
\text { Coeffic } \\
\text { ients }\end{array}$} & \multirow[b]{2}{*}{ Sig. } \\
\hline & & $\mathrm{B}$ & Std. Error & Beta & $\mathrm{t}$ & \\
\hline \multirow[t]{3}{*}{1} & (Constant) & 29.108 & 4.672 & & 6.230 & .000 \\
\hline & Fungsional & .213 & .281 & .493 & 4.759 & .000 \\
\hline & Disfungsional & .558 & .344 & .198 & 4.622 & .000 \\
\hline
\end{tabular}

a. Dependent Variable:

Motivation

Source: processed data 2020

Table 10. Path Coefficient Value

\begin{tabular}{|l|l|l|}
\hline Coefficient Path & Path Coefficient Value & Conclusion \\
\hline PyX $_{1}$ & 0.493 & $\begin{array}{l}\text { There is a functional } \\
\text { influence on work } \\
\text { motivation }\end{array}$ \\
\hline PyX $_{2}$ & $\begin{array}{c}\text { There is a dysfunctional. } \\
\text { influence on work } \\
\text { motivation }\end{array}$ \\
\hline
\end{tabular}

The results of the above calculations show that the partial path coefficient between functional (X1) and Work Motivation (Y) is 0.493 and Dysfunctional (X2) is Work Motivation (Y) is 0.198. Hypothesis testing is carried out through the $\mathrm{F}$ test statistic, provided that $\mathrm{HO}$ is rejected if Fcount> Ftable and vice versa, accept H0 if Fcount < Ftable. From the calculation, the following results are obtained: $\mathrm{F}=$ From table $\mathrm{F}$ for a significance level of 0.05 and degrees of freedom $\mathrm{db} 1=2$ and $\mathrm{db} 2=67-2-1=64$, the obtained F0.05 $(2 ; 75)=21.544$. 


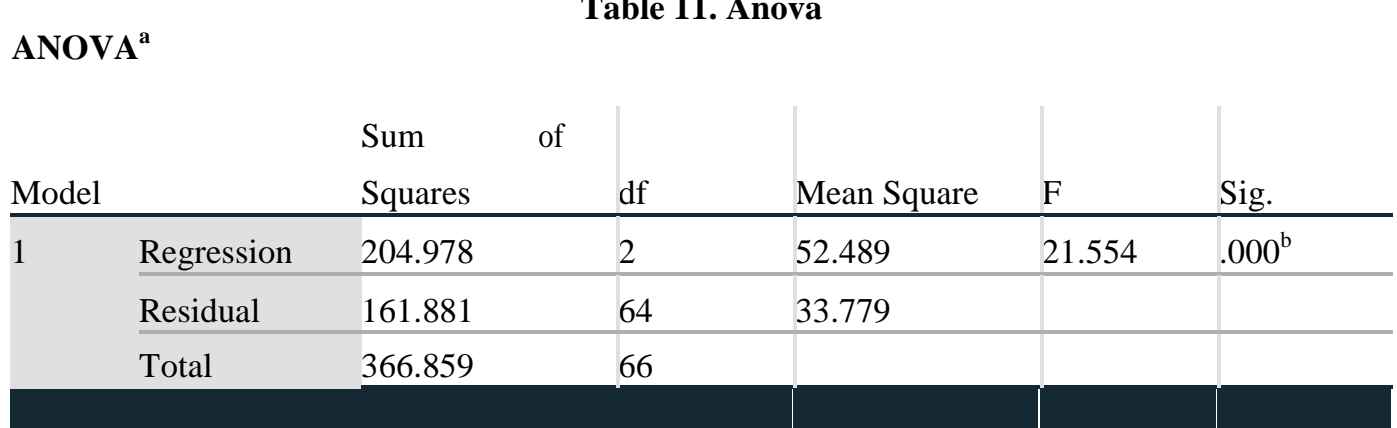

a. Dependent Variable: Motivation

b. Predictors: (Constant), Disfungsional, Fungsional

Because Fcount> Ftable, $\mathrm{H} 0$ is rejected at the 0.05 significance level. Based on the test results, it can be concluded that there is a significant (real) effect between functional (X1) and dysfunctional (X2) together on Work Motivation (Y).

Table 12. Simultaneous testing

\begin{tabular}{|l|l|l|l|l|}
\hline Alternative Hypothesis & Fcount & Ftable & Decision & Conclusion \\
\hline X1 and X2 simultaneously affect Y & 21,554 & 2.75 & H0 Rejected & Significant \\
\hline
\end{tabular}

$\mathrm{H} 0:$ pyxi $=0$ (There is no functional \& dysfunctional influence on work motivation).

$\mathrm{H} 1: \rho y x i \neq 0$ (There is a functional \& dysfunctional influence on work motivation).

for $\mathrm{i}=(1$ and 2$)$. Furthermore, this value is compared with the ttable value for $\mathrm{n}=67$ with an error rate of $5 \%$ and $\mathrm{db}=\mathrm{n}-\mathrm{k}-1=67-2-1$ is 1.669 .

Table 13. Partial Test Results

\begin{tabular}{|c|c|c|c|c|c|c|}
\hline No & Hypotesis & Path Coefficient & t-count & t-table & conclusion & decision \\
\hline 1 & $\mathrm{PyX}_{1}$ & 0.493 & 4.579 & 1.669 & H0 Rejected & Significantly \\
\hline 2 & $\mathrm{PyX}_{2}$ & 0.198 & 4.622 & 1.669 & H0 Rejected & Significantly \\
\hline
\end{tabular}

The first research hypothesis (1) states that "functional influence on work motivation". Based on the results of statistical tests with the $t$ test, it was found that tcount $=4.579>$ ttable $=$ 1.669, so that H0 was rejected, which means that Functional has an effect on dysfunctional

The second research hypothesis (2) states that "dysfunctionality affects work motivation". Based on the results of statistical tests with the $t$ test, it was obtained tcount $=$ 4.662> ttable $=1.669$; so that $\mathrm{H} 0$ is rejected, which means dysfunctional influence on work motivation.

\section{Functional Influence on Work Motivation}

The magnitude of the direct functional effect (X1) on work motivation (Y) is $24.30 \%$ and the functional indirect effect (X1) on work motivation (Y) through dysfunctional (X2) is 
7.80\%. The total effect of both direct and indirect functional (X1) on work motivation (Y) is $32.10 \%$. This means that the better the functional (X1), the better the work motivation.

Table 14. The Effect of Each Variable $X$ on $Y$

\begin{tabular}{|l|c|}
\hline Direct and Indirect Effect Big Contribution & Big Contribution \\
\hline $\mathrm{X}_{1} \quad$ Direct & $24.30 \%$ \\
\hline $\mathrm{X}_{1} \quad$ Indirect & $7,80 \%$ \\
\hline Total Effect $\mathrm{X}_{1}$ on $\mathrm{y}$ & $32,10 \%$ \\
\hline $\mathrm{X} 2 \quad$ direct & $3.92 \%$ \\
\hline $\mathrm{X}_{2} \quad$ indirect & $7.80 \%$ \\
\hline Total Effect $\mathrm{x}_{2}$ on $\mathrm{y}$ & $11,72 \%$ \\
\hline
\end{tabular}

The test results together show that the three variables, namely: functional (X1) and dysfunctional (X2) together have an effect on work motivation (Y), with the magnitude of the influence of $70.4 \%$ and the remaining $29.6 \%$ is influenced by other factors. which were not observed in this study. The results showed that work motivation was significantly influenced by functional and dysfunctional variables. Based on the results of the analysis above, it is found that work motivation is not only influenced by functional and dysfunctional. But it is also influenced by other factors. From the calculation of the coefficient of determination, the R2 value is $70.4 \%$, which means that the influence or contribution of functional and dysfunctional is $70.4 \%$ on work motivation while the remaining $29.6 \%$ is influenced by other factors or variables so that simultaneously functional and dysfunctional have an effect on work motivation and partially functional is more dominant than dysfunctional on work motivation. Done together, it is hoped that it can increase work motivation even better.

Table 15. Model Summary

Model Summary

\begin{tabular}{ll|r|r|r} 
Model & $\mathrm{R}$ & R Square & \multicolumn{1}{|c|}{$\begin{array}{c}\text { Adjusted R } \\
\text { Square }\end{array}$} & $\begin{array}{l}\text { Std. Error of the } \\
\text { Estimate }\end{array}$ \\
\hline 1 & $.839^{\mathrm{a}}$ & .704 & .690 & 3.812 \\
\hline
\end{tabular}

a. Predictors: (Constant), Disfungsional, Fungsional

\section{CONCLUSIONS}

The Department of Tourism and Culture of West Java Province in general has a functional level of conflict that is consistently carried out well even though there are still deficiencies in building work motivation for each employee, among others, still less critical, innovative, wider opportunities and more active and full of optimism.

From the research results it is known that simultaneously functional and dysfunctional have an effect on work motivation and partially functional has more dominant influence on work motivation than dysfunctional. It is hoped that there will be further research by other researchers regarding the problems of employee work stress, organizational stress, work performance and factors that influence motivation other than conflict. 


\section{REFERENCES}

Ankli, R.E. and Palliam, R. (2012), "Enabling a motivated workforce: exploring the sources of motivation", Development and Learning in Organizations, Vol. 26 No. 2, pp. 7-10.

Cahyani Eka Putri Susanti, Mochammad Al Musadieq and Ika Ruhana, 2014. Human Influence Relationships (Inter-Human Relations) and Working Environment Conditions on Performance Employees (Study of Pdada Employees of the Regency Public Works Cipta Karya Lamongan), Journal of Business Administration (JAB), Vol. 17, No. 2

Gage, N.L. \& Berliner, David, C. (1984). Educational Psychology 3rd Ed. Boston, Houghton Mifflin Company.

Hasibuan, Malayu S.P. 2011. Human Resource Management. Jakarta: Earth Literacy

Harrison, T.R. and Doerfel, M.L. (2006), "Competitive and cooperative conflict communication climates: The influence of ombuds processes on trust and commitment to the organization", International Journal of Conflict Management, Vol. 17 No. 2, pp.129-153.

Han, Che., And I Gusti Salit Ketut Netra. 2014. The Effect of Conflict on Work Stress and Employee Job Satisfaction. Journal of Management of Udayana University Vol 3/8

Hera, Roosalia, Lucia, Lotje Kawet and Irvan Trang, 2015. Effects of Work Conflict and Stress Work Productivity Is Mediated By Job Satisfaction Of University Employees Catholic De La Salle Manado, Journal of EMBA, Vol. 3 No.

Ivancevich, John M, et al. (2006). Organizational Behavior and Management Volume 2.

Erlangga Publisher. Jakarta.

Kongcharoen, J., Onmek, N., Jandang, P. and Wangyisen, S. (2019), "Stress and work motivation of primary and secondary school teachers", Journal of Applied Research in Higher Education, Vol. ahead-of-print No. ahead-of-print.

Mehta, Dubinsky, dan Anderson. 2013, Leadership style, motivation and performance in international marketing channels. Journal: European Journal of Marketing. Volume: 37, Number: $1 / 2$, pp: 50-85.

Moh. Nazir, (2013). Research Methods, Jakarta: Ghalia Indonesia

Morkevičiūtè, M. and Endriulaitienè, A. (2020), "Explaining work motivation through perceived transformational leadership: what to expect in a sample of female employees?", Gender in Management, Vol. 35 No. 6, pp. 585-599.

Mursinah and Mulyadi. (2018) The influence of motivation and work culture on

the performance of teachers in madrasah Tsanawiyah Muara Kelingi district of Musi rawas. Interprof Journal of Management, Vol 4 No. 1.

Patricia Dhiana Paramita. (2019) The effect of work conflict and workload on work stress which has an impact on employee productivity (case study at pt. la luna semarang). Journal of contemporary economics and business Vol. 5 No. 2

Rex E. McClure, (2010),"The influence of organizational culture and conflict on market orientation", Journal of Business \& Industrial Marketing, Vol. 25 Iss 7 pp. $514-524$

Rizqi Anuari, Hamidah Nayati Utami, Arik Prasetya (2017) The effect of work conflict on work stress and work motivation and its impact on organizational commitment (Study on employees of PT Pelabuhan Indonesia III (Persero) Head Office). Journal Business Administration (JAB) | Vol. 42 No.1

Robbins, Stephen P. (2001). Perilaku Organisasi: Konsep, Kontroversi, Aplikasi, Jilid 1, Edisi 8, Prenhallindo, Jakarta. 
Roy, A.L. and Perrin, C. (2018), "Managing conflicts in the nonprofit sector through organizational culture change", Journal of Organizational Change Management, Vol. ahead-of-print No. ahead-of-print

Royne, Thieme dan Levy, (2018) "How to create environmentalists: the best motivators", Journal of Business Strategy, Vol. 39 Issue: 1, pp.53-60, London. Emerald Library.

Rulestari, Sri and Eryanto Hendry (2013) The Effect of Role Conflict and Work Stress on Organizational Commitment at Salak IV Kindergarten Hospital, Bogor. Econo Science Journal, 11 (2): 1727

Ruliana, Azar, (2017). The Effect of Workload Conflict on Workload and Human Relations

Turnover Intention And Its Impact on Employee Productivity Section

Production of PT. Cakrawana Furnindo Utama Semarang, Thesis, USM, Semarang.

Sanjaya (2010) The Effect of Work Conflict and Stress on Employee Performance. (Study About Perceptions of PT. Bank Jatim (Persero) Malang Branch Against Sources

Conflict and Work Stress). Thesis Human Resource Management Study Program Brawijaya University, Malang.

Sedarmayanti. (2009). Human Resources and Work Productivity. Publisher Mandar Forward. Bandung

Subrahmanyam. 2017. Relationship between service quality, satisfaction, motivation and loyalty: a multidimensional perspective ", Quality Assurance in Education, Vol. 25 Iss 2 pp. 171188. London. Emerald Library.

Sugiyono, 2011, Administrative Research Methods, Bandung: Alfabeta.

Sugiyono, 2014, Business Research Methods, Bandung: Alfabeta

Winardi, Jasman. J, Ma'aruf. Said, Musnadi (2012) Motivation on Employee Performance with Organizational commitment as an Intervening Variable (study on Service Employees Irrigation of Aceh Province). Journal of Management Science, Syiah Kuala University. Vol. 1 Year I. No.1. ISSN: 2302-0199. 